\title{
パルプ紙試験方法の展望
}

\author{
F製紙株，式会社，奥 盘 俊 介
}

\section{Characterization of Pulp and Paper}

\author{
Shunsuke Okushima \\ Qji Paper Co., Ltd.
}

\section{1. はじめに}

近年紙の用途は複雑化し, 更に印刷速度や紙の加工 速度も高速化している。一方, 抄紙機の速度も 1,000 $\mathrm{m} / \mathrm{min}$ を超光るものが出現している。パルプに目を 移してみるとサーモメカニカルパルプの出現, 古紙パ ルプ使用量の增大など新しい動きが見られる。また， 経済の低成長時代に入り製品品質の向上及び安定化, 製造コストの低減などを目的として製造工程の自動制 御化が行われている。このような紙パ産業の動向に対 してパルプ・紙の品質評価においても新しい試験方法 の開発, あるいは自動化が必要とされている。ここで はパルプ・紙の試験方法を振り返り, 最近の新しい武 験方法について概略的に述べてみたい。

\section{2. パルプ試験}

湿潤状態のパルプの評価は，抄紙機での操業をコン トロールしたり最終製品である紙の品質をコントロー ルするのに重要である。パルプの品質を把握してその パルプが抄紙機上でどのような挙動を示し，そのパル プにより作られた紙がどのような品質のものになるか 予測する方法は，過去において種々検討されてきた。

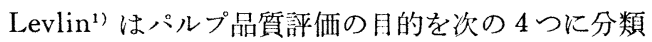
している。

(1) パルプ工場における品質管理

（2）市販用パルプ工場におけるパルプ品質の標示

（3）パルプ・紙一貫工場におけるパルプ品質の適性

（4）製紙工場における購入パルプの評価

パルプ工場では品質管理を目的としてパルプ試験方 法が必要であり，その試験方法もパルプ品質の变化を 正確に示すものであれば良い。一方, パルプ・紙一貫 工場あるいは製紙工場では, パルプの抄紙性あるいは 最終製品である紙の品質と結びついたパルプ品質の評 価が必要となる。パルプ試験としては化学的試験と物
理的試験があるが, 化学的試験は TAPPI スタンダー ドなどに詳しく述べられているので，ここでは物理的 試験についてのみ触れることにする。

従来パルプ品質の評洒は，ほとんどの場合フリーネ スの測定により行なわれてきた。フリーネス測定は簡 単であり, プロセスコントロールの手段として重要で あるが，フリーネスはパルプ品筫の独立した因子でな く，種々の因子の結合した結果であるためにその利用 には限界があると考えられている2 ${ }^{23)}$ 。すなわちフリ 一ネスは特別な条件下におけるパルプの水切れ性を示 しており,これはパルプのフィブリル化の状態, 繊維 長, 比表面積, フラクション分布などに影響される4。 例光ばGP工場において研磨直後のグラインダと研 磨後時間の経過したグラインダで作られるパルプのフ リーネスを同一にした場合，前者の裂断長 $(2.6 \mathrm{~km})$ は後者 $(3.4 \sim 4.1 \mathrm{~km})$ より小さいという報告があ る3)。

Clark $^{5)}$ はパルプ繊維の基本的特性として，長さ， 細さ, 結合性, 単緎維強度, 圧縮性をあげ, メカニカ ルパルプに対しては特に長さと細さが重要な团子であ ると強調した。近年彼はパルプ特性として粗度（coarseness), 繊維長, 単瀻維強度, 湿潤压維性, 結合性: をとりあげて，これらの特性值と晊断長，破裂強さ及 び引裂強さとの関係を理論式により検討している6 ${ }^{6}$ 。 Thode と Ingmanson") はパルプの評価方法として比 外部表面積と膨潤比容積を導入した。彼等は比外部表 面積の測定方法として次の 6 つの方法をとりあげ，水 透過法が最も適していると報告している。(1)瀻維断面 の外周測定，(2)過酸化水素之銀を用いる方法8)，(3)水 透過法, (4)染料吸着法, (5)光学的方法, (6), ガス吸着 法 また, パルプの裂断長との相関性においては, 比 外部表面積よりも水透過法により求められる潤比容積 の方が良いといら結果を示し，更に Jayme ${ }^{9}$ などによ り実験された保水值と膨潤比容積が良い相関を示すと 
報告している。

Atack と Forgacs ${ }^{10)}$ は Clark の述べた基本的特性 に比表面積の考方方を入れ，また Galley は粗度を特 性值に加えるべきと述べている10)。Forgacs ${ }^{11)}$ はメカ ニカルパルプ評洒法として䋐維長ファクタ（L）と形 状ファクタ（S）を提唱した。Lファクタは 48 メッ シュ穊上に残留する繊維の重量パーセントであり， S ファクタは 48 メッンュ通過 100 メッシュ節上に残留 する纎維の比表面積である。これら L $， \mathrm{~S}$ ファクタに ついては種々の文献で解説されているのでここでは省 略する ${ }^{12)}$ 。しかし, L , S ファクタの測定には長時間必 要であるために実際操業の管理に用いることはむつか しいのが現状である。Heerensperger ${ }^{13)}$ は Forgacs のSファクタに代り，28メッシュ通過 200 メッシュ節 上に残留する織維のフリーネス (csf) を Fファクタと し，これと裂断長，引裂強さなどとの間に良い相関性 があると報告している (図 1)。Mannström ${ }^{4}$ ) はフラ クション組成が瀻維長分布を良く示すことに基づき14), メカニカルパルプの繊維長分布は独立因子であるとし てこれを特性 $\mathrm{n}$ とた。これとともに平均瀻維長 $\mathrm{d}$

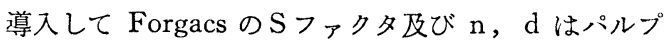
の湿紙強度, 㤠断長, 引裂強さと良く相関していると 述べいる。その他 Williams slowness testerを用い て 60/80 留分の割合を測定してパルプを評価する方法 も報告されている ${ }^{16)}$ 。れによると时 SPについて60/ 80 留分により引裂強さを予測することができる。

緘維の柔軟性をパルプマットの圧縮回復性により評

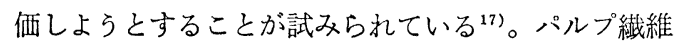

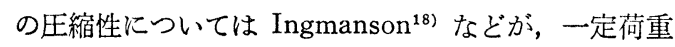
で湿潤パルプマットを压縮するとパルプ固型分濃度と 対数時間は, 直線関係汇あると報告し, 更に压縮性を 示す式として次のような実験式を提案している ${ }^{199}$ 。

$$
\mathrm{C}=\mathrm{MP}^{\mathrm{N}}
$$

$\mathrm{C}$ : パルプ固型分濃度, $\mathrm{P}$ : 圧縮荷重, $\mathrm{M}, \mathrm{N}$ : 定数 Ingmanson は圧縮性を示寸定数 $\mathrm{M}, \mathrm{N}$ が吒解を進 めても一定であると述べているが, Gertjejansen ${ }^{20)} の$ データによると吒解を進めるとMが大きくなる場合も ある。Wilder ${ }^{21)}$ は上記の圧縮特性式洔間の因子を 導入して，パルプの水透過抵抗に対するクリープの影 響を検討し，負荷後 0.001 秒から 10 分の間にクリー プのために透過抵技が增大すると報告している。この 結果は水透過法により比外部表面積などを測定する場


剛性は，それを構成している繊維の弾性率に比例する ことを導いている。この考方によるとパルプマット の王縮弾性率を湘定することにより繊維の弾性を評価
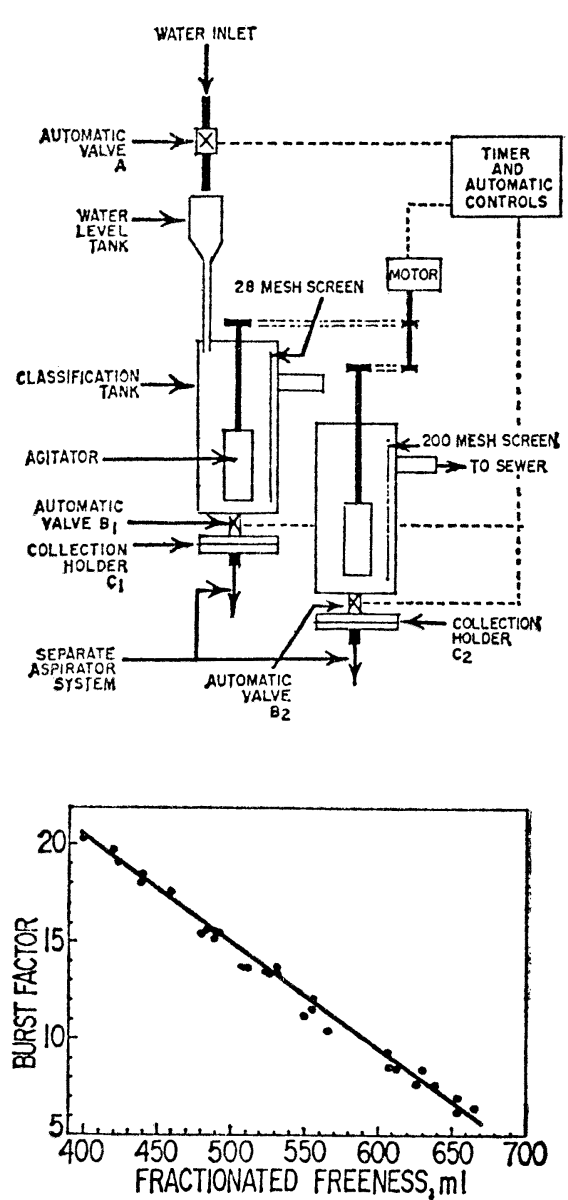

Fig. 123) Classification equipment and relationship between fractionated freeness and burst factor

することが可能となる。これまでに述べた比外部表面 積, 膨潤比容積, 圧縮珄の測定装置としては, Cowan 23)の開発した Pulmac Permeability Tester があり, これによりケミカルパルプ, メカニカルパルプの特性 を十分評価できると報告している。

Marton ${ }^{3)}$ はパルプの沈降速度がン゚ルプ の粗度, 比 表面積, 繊維長により決定されることに基いて, ホー ルパルプあるいはパルプフラクションの沈降速度と 裂断長などの強度特性を関係づけて，パルプの評価を 試みた。すなわち一般に柔軟性のあるパルプ繊維の沈 降速度は遅い。図 2 亿一例として裂断長, 引裂強さと 沈降速度の関係を示す。Marton が用いた沈降速度測 定法は次のようである。濃度 $0.2 \sim 0.5 \%$ の試料を 250 $\mathrm{m} l$ シリンダに入れ， 5 分間 $1 \mathrm{mmHg}$ で脱気した後に 真空ポンプとシリンダを結ぶバルブを締めて数回翼拌 する。その後シリンダを大気圧に戻し，この時点より 


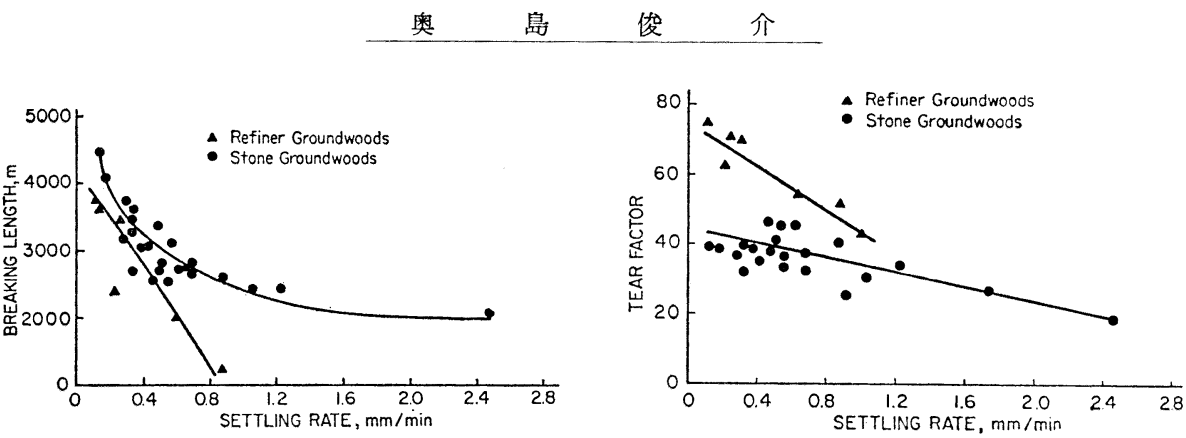

Fig. $2^{3)}$ Variation of breaking length and tear factor with settling rate

時間の測定を開始して沈降容積を時間に対してプロッ トする。この曲線に原点に打いて接線を引き，その傾 きによりパルプの初期沈降速度を求める。この場合, 沈降速度は, 水の密度や粘度に大きく影響されるので 水温を十分コントロールする必要があり，またパルプ 濃度も最適のものを選ばなければならない。一方, $\mathrm{Garceau}^{224)}$ などの実験によると,パルプの裂断長な どを評価するのに沈降速度がフリーネスより優れてい ることは確認されていない。彼等は GP とRGPを用 いてパルプ評価法の検討を行なっている。評価方法と して, (1)湿紙強度, (2)沈降速度, (3)28メッシュ節上残 量, (4)フリーネス, (5)フラクション (28メッシュ通過 200 メッシュ節上残) フリーネスをとりあげて裂断長, 引裂強さ及び破裂強度との相関性を検討した。その結 果によるとメカニカルパルプの破裂強さの特性值の代 りに, 湿紙強度を用いることを推奖している。また， 引裂強さの小さいパルプに対しては, 28 ッュュ節上 残量を引裂強度の指標に使うことができるが，引裂強 さの大きなパルプに対しては，比表面積を用いる方が 良いと述へている。更に破裂強さや裂断長に対してフ ラクションフリーネスが, ホールパルプフリーネスよ り優れていることは確認できなかったと報告している。 パルプ繊維の 膨潤性などの 評価方法として Jayme などにより保水值 $(\mathrm{WRV})^{925) \sim 28)}$ あるいは繊維飽和 点 ${ }^{29}$ の測定が行なわれている。繊維の保水值は瀻維の 微細構造に影響され, 細胞腔の大ささ, 空隙率, コラ プスビリティや外部フィブリル化の指標になる ${ }^{30)}$ 。 WRV は図 3 に示されるように裂断長と良い相関性を 持っている ${ }^{3132)}$ 。保水值の測定方法としては遠心力 ${ }^{25}$ ${ }^{26)}$ あるいは圧力差 ${ }^{30)}$ を利用する方法が報告されている。 遠心力を用いる場合は保水值の再現性を良くするため に，遠心力を十分制御する必要があり，一般に 3,000 $\mathrm{g}$ で 10 15 分間脱水後の パルプ繊維の水分量を測定 している ${ }^{25)}$ 。測定に用いるパルプの量としては，0.15 $\sim 0.5 \mathrm{~g}$ 位が用いられている。繊維飽和点 (FSP) は

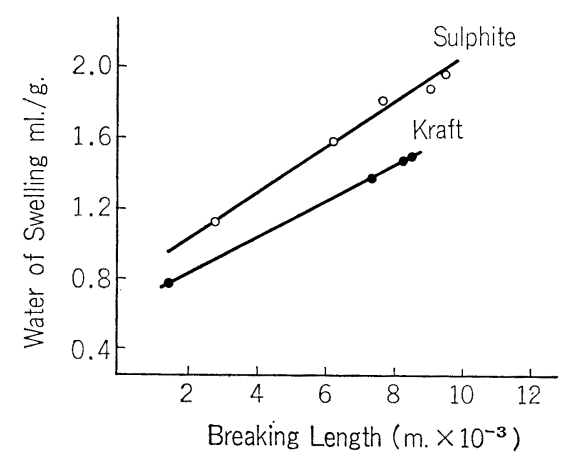

Fig. $3^{31}$ Relationship between cell wall water and breaking length for the long fiber fraction

膨潤状態における細胞膜に含まれる水分量と定義され ており, 繊維の膨潤性を示す指標になると考えられて いる。Stone ら ${ }^{29}$ は, Dextran 110 の溶液にパルプを 漫せきして Dextran 110 の濃度変化により繊維飽和 点を求めている。しかしこの方法は測定に長時間を要 し, 更に複雑な測定器が必要であるために Scallan ${ }^{33}$ らは，遠心法による保水值測定方法を応用することに より, 化学パルプの繊維飽和点の測定方法について検 討を行なった。この中で脱水時間及び遠心力の影響に ついて詳細に検討を行い, $900 \mathrm{~g}, 30$ 分脱水により求め られた保水值と Dextran 110 溶液法により求められ た繊維飽和点を比較して，図4のような結果を得た。 この結果より化学パルプについて繊維飽和点が 1.80 $\mathrm{g} / \mathrm{g}$ 以下の場合は $900 \mathrm{~g}, 30$ 分脱水の条件で遠心脱水 法により繊維飽和点を近似的に求められると述へてい る。

メカニカルパルプに打いては, シーブ (Shive) の 量あるいは大きさがその品質に影響する。シーブを測 定する方法としては Sommerville Screen あるいは PFI Minishive Analyzer ${ }^{34)}$ な゙が用いられており， またフィンランドの紙パルプ研究所で開発された 


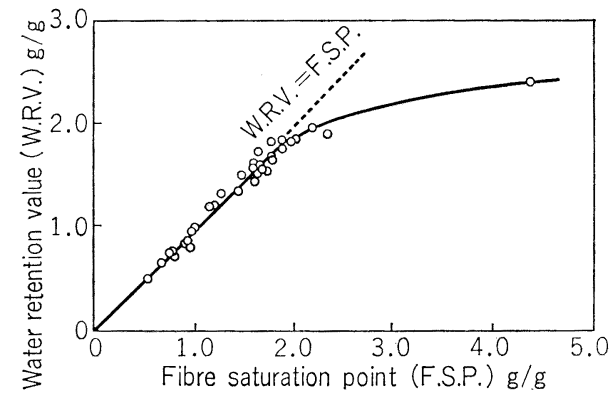

Fig. $4^{33)}$ Water retention value obtained at $900 \mathrm{~g}$ and 30 minutes plotted against the fiber saturation point

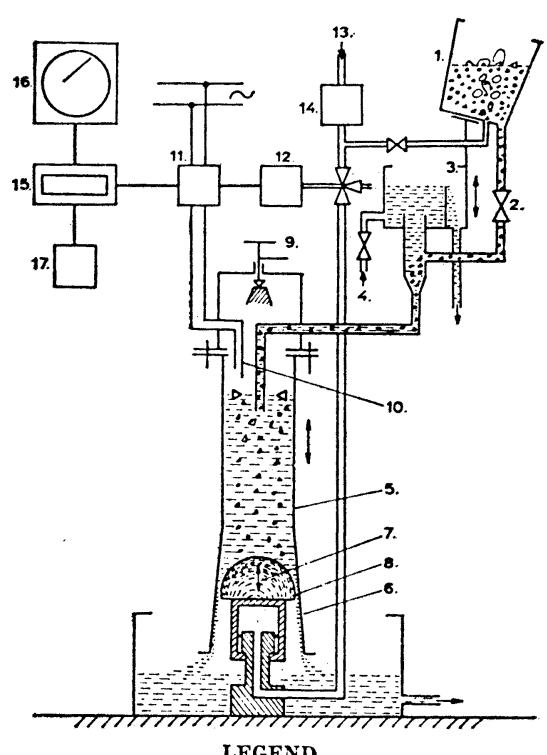

\section{LEGEND}

$\begin{array}{ll}\text { 1. Pulp tank. } & \text { 10. Contacts. } \\ \text { 2. Pulp valve. } & \text { 11. Relay. } \\ \text { 3. Water over- } & \text { 12. Air valve. } \\ \text { flow. } & \text { 13. Pressure air. } \\ \text { 4. Water inlet. } & \text { 14. Pressure re- } \\ \text { 5. Glass tube. } & \text { ducing valve. } \\ \text { 6. Ground glass } & \text { 15. Counter. } \\ \text { 7. joint. } & \text { 16. Recorder. } \\ \text { 7. Ball. } & \text { 17. Alarm device. } \\ \text { 9. Slit. } & \\ \text { knob. } & \end{array}$

Fig. $5^{35)}$ Schematic drawing of the Alfthan shive analyzer

Shive Analyzer ${ }^{35} \sim 37$ ) (図 5) も広く使用されている。 この装置は下部にスリットのあるシリンダにパルプス ラリを流し，シーブがスリットにひっかかってスリッ トをふさぐと，シリンダ中の水位が上昇する現象を利 用している。ある一定以上に水位が上昇するとカウン トを行ない，同時にスリットが開いてその結果水位は 再び降下する。一定量のパルプスラリを流す間のカウ


Fig. 6 $^{40)}$ Principle of the optical system, and measurement of width and length of shive

ント数によりシーブの量を評価する。その他視覚によ りシートの観察を行なってシーブ量を測定することも 行なわれており ${ }^{38) 391}$ ，また近年光学的方法によりシー ブの長さと幅を自動的に測定する方法も開発されてい $b^{40)}($ 図 6 )。

以上述べてきたパルプ評価方法は，いずれもその測 定に時間がかかり，プロセスコントロールを目的とし たパルプ品質の評価には適さない。従来パルプ化工程 では，例えばメカニカルパルプの場合リファイナの温 度により，あるいはクリアランスを所要動力により制 御する方法が考えられ ${ }^{41)}$ ，その後自動連続フリーネス 測定装置が関発されてフリーネスによる管理が行なわ

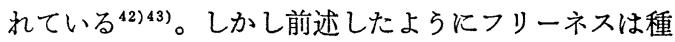
々の問題点を持っている ${ }^{12)}$ 。今後はパルプ化工程のコ ンピュータ制御化が確実に進行すると考えられ，この 場合フリーネス以外の方法により，オンラインでパル プ品質を測定する方法が不可欠である. Paulapuro ら 44)は GP プロセスの制御を目的としたパルプ評価方法 について検討しており，Forgacs らはオンラインで使 
用可能な連続式重量平均䋐維長, 比表面積及び濃度測

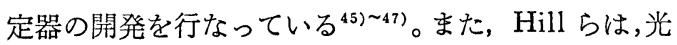
学的方法によりスラリー中の繊維の長さと幅を測定す る装置を考案し, その応用としてオンラインでのシー ブアナライザを開発して，スクリーン工程の自動制御 の方法について検討を行なった ${ }^{48)}$ 。このように今後は プロセスのコンピュータによる自動制御を目的として, オンラインに拈けるパルプ品質の評価方法あるいは装 置の開発が必要とされている。

\section{3. 紙試験}

紙の試験方法については JISや TAPPI スタンダ 一ドなどに規格されているので，ここでは最近の新し い試験方法について子れてみたい。紙の利用が複雑に なるにつれて実際的な面に応用できる試験方法の開発 が必要とされて拉り，それとともに人為的誤差を少く し，さらに測定を自動化することも要求されている。

印刷においては紙の表面強度 (linting など) ある いは層間剝離強度が重要な因子となる。すなわち繊維 間結合強度が大きな影響を与えると考えられ，これを どのように評価するかが問題となる。 Reynolds ${ }^{49}$ は Scott Internal Bond Tester ${ }^{50) 51)}$ を使ってこの点につ いての検討を行なっている。この中で internal bond test は, 引張強さや引裂強さなどの普通の測定方法上 り纎維間結合の評価沈いして有効な武器になると述 ベている。この場合剥離速度を十分大きくする必要が ある ${ }^{51)}$ 。リンティング (linting) に対する評価は， web fed offset press (Apollo, Versatec), sheet fed offset duplicator (Thatcher, Rotoprint, Lithomaster, Heidelberg, Kora, Multilith) などにより, 100〜15,000 枚の紙を通した後にブランケット上に残 留する繊維質分やちりを粘着テープにより除去して, 単位面積あたりの数を調べる70)。あるいはブランケッ 卜を洗浄し，その水をフィルタにかけて残留物の重量 を測定する方法も報告されている。その他 SCAN test method No. 30-70を応用した方法があり, 新 聞用紙を互いにこすり，毛羽立った繊維の数を数える。 実際的な印刷条件における新聞用紙などの印刷適性 を評価する方法として, GFL Rotary Test Printing

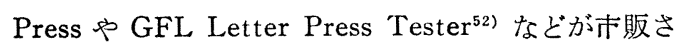
れている。また，多色刷りの評洒においては印刷の間 隔を調整することが重要であり, 従来 IGT Printing Tester ではこの間隔を $0.014 \sim 0.35$ 秒の間でのみ調 整が可能であった。しかし, 実際の多色印刷を考虑し た場合 6 秒ぐらいの長い間隔が必要であり, 印刷間隔 $0.2 \sim 6$ 秒の調節が可能な IGT Tester も市販されて
いる53)。

紙の引張強度などの品質は, 坪量の変動に影響され るところが大きい。この坪量変動を $\beta$ 線写真の microdensitometer に上る解析により評価する方法が発表

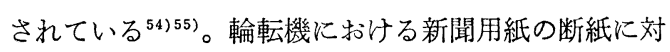
する評価方法としては, 高速引張武験が必要と考兄ら れておりこれに対してフィンランド紙パルプ研究所 で高速引張試験装置が開発され, 歪速度 $2 \times 10^{-4} \mathrm{~m} / \mathrm{s}$ $\sim 10 \mathrm{~m} / \mathrm{s}$ の範团で引張速度, 破断伸びが測定されてい る。その結果によると両者とも歪速度の增加とともに 対数的に大きくなっている。その他紙の引張試験の分 野飞未新る新しい試験器としては, 水平式半自動引張 試験器 (Weap-semi Automatic Tensile Tester: Wennberg Apparater AB), 自動データ処理装置付 引張試験器 (例党ば Tinius Olsen Model SR Automatic Tensile Tester: Tinuis Olsen Testing Machine Co., 島津オートグラフ自動データ処理装置： 島津製作所)などがある。紙加工機上あるいは印刷機 上での紙の破断に対する試験方法として, エルメンド ルフ引裂試験器が用いられているが，この試験器にお ける引裂モードが実際の輪転機上などでの引裂モード

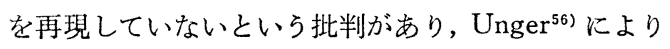
インプレイン引裂試験の方法が提案され，Van den Akker ${ }^{57)}$ などにより詳しく検討されている。更に Page ${ }^{58)}$ などは, インプレイン引裂試験も引張力によ る紙の破壊を再現しているかどらかは疑問であると述 べており，両端にノッチを入れた試料を用いてショー トスパン引張試験を行なって, 破壊エネルギを測定し ている。この破壞エネルギを破断面長さで割り, 破壊 抵抗 (Fracture Resistance) といら考方方を，紙の 輪転機上などでの走行性評価に対して提案している (図 7 )。

紙の試験特に強度試験は，一般に破壊試験により行 なわれているが，紙の強度のオンマシン測定を行なう 場合非破壊試験方法の確立がその前提となるであろら。 非破壊試験の一つの方法として超音波の利用が考兄ら

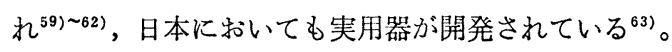
超音波の伝播速度は紙の構造, 特に繊維間結合面積に 影響されることを考兄れば, この方法をパルプの結合 性（繊維間結合強度, 柔軟性, コラプスビリティな ど）の評価に応用することも可能であるう。

以上紙の新しい試験方法について若干述べてきたが, 従来紙の評価はオフマシンで行なわれていることが多 く, このオフマシン紙試験の分野に怙ける今後の課題 は, 自動化・連続化であるう。例兄ば連続フィルム厚 さ測定器も紙の厚さ測定に応用できるものと考兄られ， 


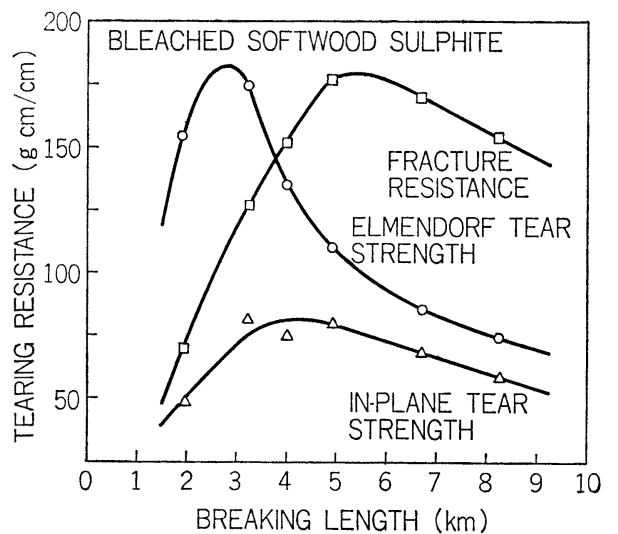

Fig. $7^{58)}$ Plot of tearing resistance against tensile strength for bleached softwood sulfite pulp

前述したように引張試験器などにおいても自動化した 測定器が開発されている。その他，紙のクリープ破壊 など時間依存的性質を短時間俉伻価できる測定方法の 開発も必要と考兄られる。更に抄紙機のコンピュータ コントロールを目的として紙の品質 (引張強さ, 引裂 強さ, 平滑度, 白色度など)をオンマシンで測定す ることが急務であろう。この点については数年前に TAPPI に特集されている6 ${ }^{64)}$ 。その後オンマシンにお ける強度 ${ }^{65}$, 緊度 ${ }^{66)}$, 白色度, 不透明度, 光沢 ${ }^{67) ~ 69) ~}$ の測定についての報告がみられる。

\section{引用文献}

1) J.E.Levlin : Tappi, 58(1), 71/74 (1975)

2) J.J.Garceau : P.T.J., 158(8), 28 (1972)

3) R.Marton: Tappi, 52(12), 2400/2408 (1969)

4) B.Mannstrom : Paperi Ja Puu, 49(4 a), 137/ 146 (1967)

5) J.d'A.Clark : P.P.M.C., 59(10), 134/137 (1958)

6) J.d'A.Clark: Tappi, 56 (7), 122/125 (1973)

7) E.F.Thode and W.L.Ingmanson: Tappi, 42 (1), 74/83 (1959)

8) B.L.Browing : Tappi, 33(8), 410/412 (1950)

9) G.Jayme, etc. : Das Papier, 12, 90/92 (1958)

10) D.Atack and O.I.Forgacs : P.P.M.C., 62(3), T 187/T 194 (1961)

11) O.L.Forgacs : P.P.M.C., 64(C), T89/T 116 (1963)

12) 高橋 裕 : 化学装置, $17(2), 40 / 48$ (1975)

13) B.D.Heerensperger : Tappi, 49(8), 94A/97A (1966)
14) U.Ullman, etc. : Svensk Papperstidn., 68(7), 230/235 (1965)

15) J.N.Stephenson : Pulp and Paper Manufacture, McGraw Hill Vol. 2, 239 (1951)

16) F.L.Wells and R.F.Stumph, Tappi, 49(8), 353/356 (1966)

17) C.O.Seborg : P.T.J., 113(7), 49 (1941)

18) W.L.Ingmanson and R.P.Whitney : Tappi, 37 (11), 523/534 (1954)

19) W.L.Ingmanson : Tappi, 35 (10), $439 / 448$ (1952)

20) R.O.Gertjejansen : Tappi, 47 (1), 19/21 (1964)

21) H.D.Wilder : Tappi, 43(8), 715/719 (1960)

22) R.Meyer and D.Wahren : Svensk Papperstidn., 67(10), 432/436 (1964)

23) W.F.Cowan : P.P.M.C., 71(9), 63/66 (1970)

24) J.J.Garceau and H.C.Lvallee : Pulp \& Paper Can., 76(3), T67/T73 (1975)

25) G.Jayme : Tappi, 41(11), 180A/183A (1958)

26) B.Anderson and O.Samuelson: Svensk Papperstidn., 61(24), 1001/1009 (1958)

27) T.Hopner and G.Jayme : Das Papier, 9(19/20), 476/482 (1955)

28) G.Jayme and H.Buttel : Das Papier, 20(7), $357 / 366$ (1966)

29) J.E.Stone and A.M.Scallan : Tappi, 50(10), 496/501 (1967)

30) A.A.Robertson: Consolidation of the Paper Web, 90/118 (1966)

31) J.E.Stone and A.M.Scallan : Svensk Papperstidn., 71(19), 687/694 (1968)

32) G.Jayme and E.Roffael : Das Papier, 24(6), $335 / 340$ (1970)

33) A.M.Scallan and J.E.Carles : Svensk Papperstidn., 75(17), 699/703 (1972)

34) R.B.Kerr \& P.M.Shallhorn : Pulp \& Paper Can., 77 (9), 81/85 (1976)

35) G.V.Alfthan : P.P.M.C., 66(4), T229/T240 (1965)

36) A.Karnis and R.S.Allan : P.P.M.C., 68(8), T359/T366 (1967)

37) J.R.Stephens and A.J.Pearson : Appita, 24(5), 325/337 (1971)

38) W.F.Cowan : P.P.M.C., 70(1), 65/69 (1969)

39) B.Kyrklund \& M.Makinen : Paperi ja Puu, $51(8), 601 / 604$ (1969) 


奥島 优 介

40) H.Hoglund and E.Johnsson : Svensk Pappers tidn., 79(13), 411/417 (1976)

41) C.Owensby : P.T.J., 151(16), 44/49 (1967)

42) J.S.Ottersen and D.T.Powell : P.P.M.C., 75 (6), T229/T233 (1974)

43) H.S.Gilbert : P.T.J., 155(25), 32/35 (1971)

44) H.Paulapuro and N.Ryti : Pulp \& Paper Can., 77(6), T111/T118 (1976)

45) A.Karnis and O.L.Forgacs : P.P.M.C., 73(12), T362/T367 (1972)

46) O.L.Forgacs \& A.Karnis : U.S. Pat., 3802964 (1974)

47) O.L.Forgacs and A.Karnis : U.S. Pat., 3873416 (1975)

48) J.Hill and L.Eriksson : Pulp \& Paper Can., 77 (4), T80/T 85 (1976)

49) W.F.Reynold : Tappi, 57 (3), 116/120 (1974)

50) A.F.Blockman and W.C.Wikstrand : Tappi : 41(3), 191A/194A (1958)

51) 張 恒雄, 他 : 第 27 回日本木材学会大会

52) Lorentzen \& Wettres : カタログ

53) Paper, 181(5), 246 (1974)

54) P.A.Tydeman: The Paper Maker, 153(6), 42/48 (1967)
55) B.Nordman \& D.Wahren : Svensk Papperstidn., 77(11), 397/406 (1974)

56) E.Unger : Zellstoff Papier, 9(3), 99 (1960)

57) J.A.Van den Akker and W.A.Wink : Tappi, 50(9), 466/470 (1967)

58) R.S.Seth and D.H.Page : International Paper Physics Conference (1975)

59) J.K.Craver and D.L.Taylor : Tappi, 48(3) : 142/147 (1965)

60) D.L.Taylor and J.K.Craver : Consolidation of the Paper Web, 852/873 (1966)

61) M.Jackson and G.Gavelin : Svensk Pappertidn., $70(3), 63 / 69$ (1967)

62) P.K.Chatterjee : Tappi, 52(4), 699/704 (1969)

63) 本間忠一: 繊維と工業, 5(2), 102/104 (1972)

65) M.T.Lu : Tappi, 58(6), 80/81 (1975)

66) C.A.Vossberg : Tappi, 58(6), 82/84 (1975)

67) J.D.Renigis and F.A.McMillan : Appita, 29 (1), 41/45 (1975)

68) J.S.Christie : Tappi, 60(2), 119/121 (1977)

69) W.A.Wickstrom : Tappi, 55(11), 1588/1591 (1972)

70) E.H.Snider : $63 \mathrm{rd}$ Annual Meeting of the Technical Section, CPPA (1977) 